\title{
IMPLEMENTASI PROGRAM PENGUATAN PENDIDIKAN KARAKTER (PPK) DI SDN MANGKANG WETAN O2 KOTA SEMARANG
}

\author{
Rise Aditya Anggraeni ${ }^{1}$ dan Soedjono ${ }^{2}$
}

\begin{abstract}
Character Education Strengthening Program is an educational movement under the responsibility of the education unit to strengthen the character of students through harmonization of the process of heart, taste, thought processing, and sports with involvement and cooperation between education units, families and communities as part of the National Movement Mental Revolution (GNRM). The purpose of this study was to determine the implementation of Character Education Strengthening in Mangkang Wetan 02 Elementary School Semarang City. This study uses a qualitative method, meaning that the main instrument in the study is the researcher himself. Data sources used include primary data sources and secondary data. The results showed that the implementation of Character Education Strengthening in Mangkang Wetan 02 Elementary School Semarang City was quite successful this can be seen from the level of decline in student delinquency but still needs improvement in the phenomenon of the implementation of school-based character education.
\end{abstract}

\section{Keywords: Character Education Strengthening, program implementation}

\section{PENDAHULUAN}

Pemerintah berupaya mewujudkan tujuan nasional bangsa yang kaitannya dengan mencerdaskan kehidupan bangsa melalui pendidikan dengan mencetak generasi-generasi yang memiliki kecerdasan baik spiritual, kepribadian dan keterampilan. Tentu saja tantangan dalam upaya mencerdaskan kehidupan bangsa tidaklah mudah. Globalisasi telah membawa dampak negatif seperti kekerasan, pemaksaan, penganiayaan terhadap teman, penggunaan obat terlarang bahkan pelecehan seksual. Pada tahun 2006, BNN kembali melakukan penelitian, dari hasil penelitian terungkap sebanyak 8.500 siswa sekolah dasar di Indonesia mulai mengomsumsi bahkan sudah kecanduan narkoba dalam satu tahun terakhir. Hasil kajian Konsorsium Nasional PengembanganSekolah Karakter tahun 2014 menyebutkan, hampir setiap sekolah diIndonesia ada kasus bullying, meski hanya bullying verbal danpsikologis/mental. Kasus-kasus senior menggencet junior terusbermunculan. Statistik kasus pengaduan anak di sektor pendidikan dariJanuari 2011

\footnotetext{
${ }^{1}$ Mahasiswa Prodi S2 Ilmu Administrasi, Departemen Adm Publik, Universitas Diponegoro

2 Dosen Prodi S2 Ilmu Administrasi, Departemen Adm Publik, Universitas Diponegoro
} 
hingga Agustus 2014 tergambar sbb: Tahun 2011 terdapat61, tahun 2012 terdapat 130 kasus, tahun 2013 terdapat 91 kasus,tahun 2014 terdapat 87 kasus.Tahun 2015 kasus kenakalan lainnya pembegalan motor di jalan Margonda Depok yang pelakunya masih usia Remaja. Banyak berita dari media cetak maupun elektronik yang berisi unsur-unsur anarkis, destruktif dan memecah belah bahkan hingga memakan korban jiwa. Oleh sebab itu pemerintah perlu memutuskan suatu program yang memperbaiki nilai moral, akhlak dan kepribadian bangsa dalam dunia yang penuh dengan tantangan globalisasi.

Melihat semakin merosotnya karakter generasi ini maka diperlukan suatu cara agar pemerintah dapat memperlihat taringnya untuk memperbaiki karakter bangsa Indonesia sesuai dengan Agenda Nawa Cita No. 8 yang diusung oleh Jokowi JK yaitu melakukan revolusi karakter bangsa melalui kebijakan penataan kembali kurikulum pendidikan nasional dengan mengedepankan aspek pendidikan kewarganegaraan, yang menempatkan secara proporsional aspek pendidikan, seperti pengajaran sejarah pembentukan bangsa, nilai-nilai patriotisme dan cinta tanah Air, semangat bela negara dan budi pekerti di dalam kurikulum pendidikan Indonesia. Demi menyongsong Generasi Emas tahun 2045, Presiden Jokowi melakukan pembangunan besar-besaran di berbagai bidang. Salah satunya adalah pembangunan SDM yang menjadi fondasi pembangunan bangsa. Pemerintah mengeluarkan Peraturan Presiden No. 87 tahun 2017 tentang Penguatan Pendidikan Karakter yang digadang-gadang menjadi program untuk memperbaiki karakter bangsa. Diuraikan dalam pasal 1 ayat 1 Penguatan Pendidikan Karakter (PPK) adalah gerakan pendidikan di bawahtanggung jawab satuan pendidikan untukmemperkuat karakter peserta didik melaluiharmonisasi olah hati, olah rasa, olah pikir, dan olahraga dengan pelibatan dan kerja sama antara satuanpendidikan, keluarga, dan masyarakat sebagai bagiandari Gerakan Nasional Revolusi Mental (GNRM).

Penguatan Pendidikan Karakter (PPK) dilaksanakan oleh satuan pendidikan SD dan SMP di seluruh Indonesia di bawah pengawasan Kementerian Pendidikan dan Kebudayaan (Kemendikbud). SDN Mangkang Wetan 02 menjadi sasaran pelaksana karena sebagai salah satu SD inti di Kecamatan Tugu.

Lokasi yang sangat rawan dengan lingkungan lokalisasi, judi dan pemabuk membuat para siswa rentan akan pengaruh negatif ini. Latar belakang ekonomi dan pendidikan keluarga yang kurang memadai juga membawa pengaruh besar bagi perkembangan karakter siswa. 
Tabel. 1.1 TingkatPendidikan Orang Tua Siswa SDN Mangkang Wetan 02

\begin{tabular}{|c|l|c|c|}
\hline NO & $\begin{array}{c}\text { JENIS } \\
\text { PENDIDIKAN }\end{array}$ & FREKUENSI & PERSENTASE \\
\hline 1 & Putus SD & 19 & $8 \%$ \\
\hline 2 & SD & 27 & $12 \%$ \\
\hline 3 & SMP & 61 & $27 \%$ \\
\hline 4 & SMA/ SMK & 110 & $48 \%$ \\
\hline 5 & D3/ S1 & 12 & $5 \%$ \\
\hline 6 & S2 & 0 & $0 \%$ \\
\hline & JUMLAH & $\mathbf{2 2 9}$ & $\mathbf{1 0 0 \%}$ \\
\hline
\end{tabular}

Sumber: Bagian Administrasi SDN Mangkang Wetan 02

Pendidikan orang tua siswa SDN Mangkang Wetan 02 yang berada pada no 1, 2, 3 dan 4 yaitu putus sekolah, SD, SMP dan SMA/ SMK sebanyak 95\% dari seluruh orang tua siswa. Mereka tidak sempat untuk menempuh pendidikan yang lebih tinggi karena selain alasan ekonomi dan pengaruh social yang menikah diusia muda, mereka dipersiapkan sedini mungkin untuk siap kerja. Sehingga pemikiran dari 95\% orang tua ini cenderung kurang memperhatikan kebutuhan pendidikan, sikap, dan tutur kata anaknya. Perbaikan karakter hanya diserahkan secara sepihak kepada pihak sekolah, yang menyebabkan kurangnya pengawasan di luar sekolah. Pengawasan orang tua terhadap kebutuhan pendidikan anak seperti menemani saat belajar, membuatkan sarapan untuk anak, melakukan konsultasi perkembangan siswa saat di sekolah, memenuhi panggilan sekolah saat terjadi pelanggaran yang di lakukan siswa seringkali dihiraukan. Beberapa siswa berpotensi mempunyai perilaku yang negative yang dapat menimbulkan pengaruh kepada siswa lainnya seperti terbentuknya geng yang mendominasi, korban bullying, perkelahian anatar siswa, tawuran dan lainnya. 
Tabel. 1.2 Jenis Kenakalan Siswa SDN Mangkang Wetan 02

Periode Agustus-November 2017

\begin{tabular}{|c|c|c|c|c|}
\hline NO & $\begin{array}{c}\text { TINGKAT } \\
\text { KENAKALAN }\end{array}$ & $\begin{array}{c}\text { JENIS KENAKALAN } \\
\text { SISWA }\end{array}$ & FREKUENSI & Persentase \\
\hline 1 & \multirow{4}{*}{ Ringan } & Mengejek & 102 & $44 \%$ \\
\hline 2 & & Berkata kotor/mengumpat & 80 & $34 \%$ \\
\hline 3 & & $\begin{array}{l}\text { Menggunakan atribut sekolah } \\
\text { yang tidak sesuai }\end{array}$ & 42 & $18,1 \%$ \\
\hline 4 & & Terlambat sekolah & 22 & $9,4 \%$ \\
\hline 5 & \multirow{3}{*}{ Sedang } & Mewarnai rambut & 31 & $13,4 \%$ \\
\hline 6 & & Berkelahi & 24 & $10,3 \%$ \\
\hline 7 & & Membolos & 12 & $5,2 \%$ \\
\hline 9 & \multirow{4}{*}{ Berat } & $\begin{array}{l}\text { Tidak mengikuti ibadah } \\
\text { sholat dhuhur }\end{array}$ & 25 & $11,7 \%$ \\
\hline 8 & & Merokok & 32 & $13,8 \%$ \\
\hline 10 & & Melecehkan teman & 12 & $5,2 \%$ \\
\hline 11 & & Membawa senjata tajam & 4 & $1,7 \%$ \\
\hline
\end{tabular}

Sumber: Bagian Administrasi SDN Mangkang Wetan 02

Dari tabel 1.2 dapat dilihat beberapa kenakanan siswa yang terjadi pada Bulan Agustus-November 2017. Dapat dilihat bahwa kenakalan siswa tertinggi hingga terendah yaitu: Mengejek satu sama lain 44\%, berkata kotor/ mengumpat 34\%, menggunakan atribut sekolah yang tidak sesuai $18,1 \%$, merokok $13,8 \%$, mewarnai rambut $13,4 \%$, tidak mengikuti ibadah sholat dhuhur $11,7 \%$, berkelahi $10,3 \%$, terlambat sekolah $9,4 \%$, melecehkan teman5,2\%, membolos 5,2\%, dan membawa senjata tajam 1,7\%.

Dalam menanggulangi kenakalan siswa tersebut pihak sekolah telah bekerja sama dengan komite sekolah, Babinkamtipmas (Bintara pembinanaan dan keamanan ketertiban masyarakat)/Polresdan Babinsa (Bintara Pembina Desa)/ Koramilkelurahan Mangkang Wetan, namun masih ada saja siswa yang mengulangi perbuatan tersebut. Hal ini pula yang membuat perbaikan karakter siswa kurang berhasil karena kerja sama antara orang tua dan sekolah yang kurang terjalin dengan harmonis.

Penelitian ini bertujuan untuk (1) Menganalisis implementasi Program Penguatan Pendidikan Karakter (2) Mengeksplorasi faktor yang menghambat dan mendorong keberhasilan implementasi program Penguatan Pendidikan Karakter (PPK) di SDN Mangkang Wetan 02. 


\section{Metode Penelitian}

Penelitian menggunakan metode deskriptif dengan model implementasi program yang digunakan adalah George C. Edward III. Pendekatan penelitian ini dilakukan untuk menganalisis implementasi program PPK dan mengeksplor faktor pendorong dan penghambat terlaksanannya program PPK di SDN Mangkang Wetan 02 sebagai penerapan Perpres No. 87 tahun 2017 mengenai Penguatan Pendidikan Karakter.

\section{PEMBAHASAN}

SDN Mangkang Wetan 02 merupakan pelaksana program pendidikan karakter di wilayah Kec. Tugu Kota Semarang. Kegiatan Pendidikan karakter ini berupa kegiatan pembiasaan yang bermanfaat untuk mengubah karakter siswa menjadi lebih religius, nasionalis, mandiri, gotong royong dan integritas.

Kegiatan pembiasaan tersebut meliputi program harian, mingguan, bulanan dan tahunan. Ada beberapa kegiatan yang sudah dilakukan dan ada pula yang belum terlaksana.

Tabel 1.3

\section{Program Pembiasaan di SDN Mangkang Wetan 02}

\begin{tabular}{|c|c|c|c|}
\hline No. & $\begin{array}{l}\text { Pelaksanaan } \\
\text { Kegiatan } \\
\text { Pembiasaan }\end{array}$ & Jenis Kegiatan Pembiasaan & Penanggung jawab \\
\hline \multirow[t]{2}{*}{1} & Kegiatan Umum & Imunisasi dari Puskesmas & $\begin{array}{l}\text { Puskesmas } \\
\text { Mangkang }\end{array}$ \\
\hline & & $\begin{array}{l}\text { Sosialisasi kenakalan anak dan } \\
\text { remaja }\end{array}$ & $\begin{array}{l}\text { Babinkamtibmas, } \\
\text { Babinsa dan KS }\end{array}$ \\
\hline \multirow[t]{8}{*}{2} & Kegiatan Harian & $\begin{array}{l}\text { Menyambut kedatangan siswa } \\
\text { dengan 3S dan bersalam-salaman }\end{array}$ & Semua guru \\
\hline & & Pembacaan asmaul husna & Guru PAI \\
\hline & & Literasi & Guru Kelas \\
\hline & & $\begin{array}{c}\text { Menyanyikan lagu Kebangsaan } \\
\text { Indonesia Raya }\end{array}$ & $\begin{array}{c}\text { Guru dan Siswa } \\
\text { Piket }\end{array}$ \\
\hline & & $\begin{array}{c}\text { Pasuskes (Pasukan Khusus } \\
\text { Kebersihan) }\end{array}$ & $\begin{array}{l}\text { Guru dan Siswa } \\
\text { Piket }\end{array}$ \\
\hline & & $\begin{array}{l}\text { Cuci tangan sebelum dan sesudah } \\
\text { makan }\end{array}$ & $\begin{array}{c}\text { Guru dan Siswa } \\
\text { Piket }\end{array}$ \\
\hline & & $\begin{array}{c}\text { Menyanyikan lagu daerah } \\
\text { nusantara }\end{array}$ & Guru Kelas \\
\hline & & $\begin{array}{l}\text { Sholat dhuhur berjamaah sesuai } \\
\text { jadwal }\end{array}$ & $\begin{array}{c}\text { Guru PAI dan Guru } \\
\text { Kelas }\end{array}$ \\
\hline
\end{tabular}




\begin{tabular}{|c|c|c|c|}
\hline 3 & Kegiatan Mingguan & Upacara Bendera Hari Senin & $\begin{array}{c}\text { Guru dan Petugas } \\
\text { upacara }\end{array}$ \\
\hline & & Membaca surat-surat pendek & Guru PAI \\
\hline & & Sabtu Sehat & Guru OR \\
\hline & & Potong kuku & Guru Kelas \\
\hline 4 & Kegiatan Bulanan & $\begin{array}{c}\text { Ektra kurikuler (pramuka, } \\
\text { paskibra, tari, silat, rebana) }\end{array}$ & Gerakan Gemar Menabung \\
\hline & & Gosok Gigi & Guru Kelas \\
\hline 5 & Kegiatan tahunan & Pesantren kilat & Siswa dan gasurkes \\
\hline & & $\begin{array}{c}\text { Peringatan Hari Besar Keagamaan } \\
\text { dan Nasional }\end{array}$ & $\begin{array}{c}\text { Guru PAI dan } \\
\text { penjaskes }\end{array}$ \\
\hline & & Istighosah & Guru PAI \\
\hline & & $\begin{array}{c}\text { Lomba siswa (POPDA, MAPSI, } \\
\text { Pramuka, Siswa Prestasi, dll) }\end{array}$ & $\begin{array}{c}\text { Guru PAI dan } \\
\text { Penjas }\end{array}$ \\
\hline & & Pentas Seni Akhir Tahun & $\begin{array}{c}\text { Smua guru dan } \\
\text { guru ekstra }\end{array}$ \\
\hline
\end{tabular}

Sumber: Bagian Administrasi SDN Mangkang Wetan 02

Implementasi Pendidikan Karakter di SDN Mangkang Wetan 02 memberikan dampak besar bagi perubahan karakter siswa. Pembiasaan-pembiasaan yang dilaksanakan di SDN Mangkang Wetan 02 membuat siswa yang berperilaku buruk berangsur-angsur memperbaiki sikapnya. Perubahan perilaku ini seperti menggunakan atribut sekolah yang tidak sesuai, merokok mewarnai rambut, tidak mengikuti ibadah sholat dhuhur, berkelahi, melecehkan teman, terlambat sekolah, membolos, membawa senjata tajam terjadi penurunan persentase. Sedangkan untuk jenis kenakalan mengejek, dan berkata kotor mengalami kenaikan. Perubahan ini dapat dilihat pada tabel de bahawah ini. 
Tabel 1.4

Penurunan Kenakalan Siswa Setelah Pelaksanaan Program Penguatan

Pendidikan Karakter

\begin{tabular}{|c|l|l|c|c|c|}
\hline NO & \multicolumn{1}{|c|}{ TINGKAT } & \multicolumn{1}{|c|}{ JENIS } \\
KENAKALAN & \multicolumn{1}{|c|}{ SISWA } & $\begin{array}{c}\text { FREKUENSI } \\
\text { SEBELUM } \\
\text { PPK }\end{array}$ & $\begin{array}{c}\text { FREKUENSI } \\
\text { SETELAH } \\
\text { PPK }\end{array}$ & $\begin{array}{c}\text { PENURUNAN } \\
\text { PERSENTASE }\end{array}$ \\
\hline 1 & Ringan & Mengejek & 102 & 116 & $\begin{array}{c}44 \%-53 \%= \\
(-9 \%)\end{array}$ \\
\hline 2 & Ringan & $\begin{array}{l}\text { Berkata kotor/ } \\
\text { mengumpat }\end{array}$ & 80 & 91 & $\begin{array}{c}34 \%-42 \%= \\
(-8 \%)\end{array}$ \\
\hline 3 & Ringan & $\begin{array}{l}\text { Menggunakan } \\
\text { atribut sekolah } \\
\text { yang tidak sesuai }\end{array}$ & 42 & 38 & $\begin{array}{c}18,1 \%-17,4 \%= \\
(0.7)\end{array}$ \\
\hline 4 & Berat & Merokok & 32 & 0 & $\begin{array}{c}13,8 \%-0 \%= \\
13,8 \%\end{array}$ \\
\hline 5 & Sedang & Mewarnai rambut & 31 & 21 & $\begin{array}{c}13,4 \%-9,6 \%= \\
3,8 \%\end{array}$ \\
\hline 6 & Berat & $\begin{array}{l}\text { Tidak mengikuti } \\
\text { ibadah sholat } \\
\text { dhuhur }\end{array}$ & 25 & 14 & $\begin{array}{c}11,7 \%-6,4 \%= \\
5,3 \%\end{array}$ \\
\hline 7 & Sedang & Berkelahi & 24 & 18 & $\begin{array}{c}10,3 \%-8,2 \%= \\
2,1 \%\end{array}$ \\
\hline 8 & Ringan & Terlambat sekolah & 22 & 12 & $\begin{array}{c}9,4 \%-5,5 \%= \\
3,9 \%\end{array}$ \\
\hline 9 & Berat & Melecehkan teman & 12 & 0 & $\begin{array}{c}5,2 \%-0 \%= \\
12 \%\end{array}$ \\
\hline 10 & Sedang & Membolos & $\begin{array}{l}\text { Membawa senjata } \\
\text { tajam }\end{array}$ & 4 & $\begin{array}{c}5,2 \%-1,3 \%= \\
3.9 \%\end{array}$ \\
\hline 11 & Berat & Sum & 12 & $\begin{array}{c}1,7 \%-0 \%= \\
4 \%\end{array}$ \\
\hline
\end{tabular}

Sumber: Bagian Administrasi SDN Mangkang Wetan 02

Implementasi pendidikan Karakter di SDN Mangkang Wetan 02 ini berdasarkan pada hasil wawancara yang dilakukan terhadap lima orang informan yang dipilih, yaitu Kepala UPTD Pendididkan Kec.Tugu, Pengawas SDN Mangkang Wetan 02, Kepala Sekolah SDN Mangkang Wetan 02, Guru Pembina PPK dan Komite sekolah selaku wakil orang tua/ wali murid siswa SDN Mangkang Wetan 02. Implementasi Pendidikan Karakter di SDN Mangkang Wetan 02 bertujuan untuk:

1. Menganalisis implementasiProgram Penguatan Pendidikan Karakter.

2. Mengeksplorasi faktor yang menghambat dan mendorong keberhasilan implementasi program Penguatan Pendidikan Karakter (PPK) di SDN Mangkang Wetan 02. 
Dari rincian di atas maka dapat diambil kesimpulan bahwa tujuan dari implementasi adalah untukmemberi rekomendasi tentang permasalahan implementasi pendidikan karakter di Kota Semarang.

Berikut adalah implementasi pendidikan karakter berbasis budaya di level sekolah yang disampaikan oleh Kementerian Pendidikan dan Kebudayaan tahun 2017 yang berdasarkan 4 indikator: Pembiasaan nilai-nilai harian sekolah, keteladanan pendidik, Ekosistem sekolah dan Norma, peraturan sekolah dan tradisi sekolah.

Berdasarkan uraian hasil penelitian dan pembahasan tentang Implementasi Pendidikan Karakter di SDN Mangkang Wetan 02, maka dapat disimpulkan bahwa implementasi pendidikan karakter di SDN Mangkang Wetan 02 belum berhasil hal ini dapat dilihat dari fenomena pendidikan karakter berbasis budaya sekolah dengan sub fenomena:

1. Pembiasaan nilai-nilai dalam keseharian sekolah; Sudah terdapat program yang terencana di awal tahun ajaran baru yang meliputi program harian, mingguan, bulanan dan tahunan. Namun pada program tahunan ada satu program yang belum terlaksana.

2. Keteladanan pendidik; Belum 100\% guru dan staf memberikan keteladanan bagi siswanya. Perlu adanya ketegasan dan reward dari pimpinan.

3. Ekosistem sekolah; Lingkungan fisik, akademik, social dan afektif yang belum berjalan harmonis seperti tidak ada slogan-slogan yang membuat semangat siswa, prestasi yang kurang ditonjolkan dan pengelolaan mading yang belum sempurna, juga tutur bahasa siswa yang masih terbawa bahasa local Jawa Ngoko membuat karakter siswa kurang terbangun.

4. Norma, peraturan sekolah dan tradisi sekolah; Norma, peraturan sekolah dan tradisi sekolah yang secara berangsur-angsur ditaati oleh siswa membuat semakin kecilnya pelanggaran yang terjadi di sekolah.

Adapun faktor-faktor yang menghambat dan mendukung implementasi pendidikan karakter di SDN Mangkang Wetan 02 menurut George C. Edward III:

1. Sikap Pelaksana/ Disposisi; meliputi sub fenomena: persepsi pelaksana, respon pelaksana dan tindakan pelaksanaimplementasi program Penguatan Pendidikan Karakter dalam hal persepsi pelaksana, seluruh guru dan staf menyambut baik program pendidikan karakter dengan membuat program pembiasaan yang 
mengubah karakter siswa dan memasukkan nilai-nilai karakter dalam pembelajaran. Namun pada respon pelaksana dan tindakan pelaksana masih belum maksimal. Pelaksana merespon dan mendukung inovasi program namun belum terlihat hasilnya, keterlibatan guru dan orang tua juga masih kurang karena belum siap untuk menghadapi program yang disosialisasikan.

2. Sumber Daya; meliputi sub fenomena kemampuan sumber daya manusia pelaksana PPK dan penyediaan fasilitas-fasilitas yang mendukung kebijakan pendidikan karakter. Kemampuan sumber daya manusia pelaksana PPK seperti guru dan staf masih terfokus pada pembelajaran belum pada pembentukan karakter siswa. Fasilitas pendukung implementasi pendidikan karakter masih kurang. Tidak ada tenaga perpustakaan, lapangan, laboratorium, kebun sekolah dan sarana dan prasana yang memadai untuk kegiatan ekstra.

3. Komunikasi; meliputi sub fenomena intensitas sosialisasi implementasi program PPK, kejelasan dan konsistensi perintah-perintah implementasi program PPK. Sosialisasi pendidikan karakter dari sekolah sudah dilakukan walaupun tidak secara periodik. Sekolah selalu menyinggung mengenai pendidikan karakter kepada orang tua siswa. Namun sepertinya kurang adanya tanggapan dari orang tua/ walimurid. Sekolah juga telah mengajak orang tua/ walimurid untuk studi banding ke sekolah lain. Namun greget untuk menjadikan sekolah sebagai tempat belajar siswa masih kurang. Mengenai kejelasan sosialisasi, para pelaksana sudah mengetahui dengan jelas tujuan pendidikan karakter untuk membentuk karakter siswa sehingga menjadi kader bangsa yang berakhlak dan berprestasi. Pemerintah sudah konsisten mengenai petunjuk implementasi pendidikan karakter. Perintah yang dilakukan tidak berubah-ubah. Namun karena program pendidikan karakter ini merupakan program yang baru, sekolah masih meraba-raba kebijakan yang harus diambil dan akan dibentuk seperti apa agar pendididkan karakter itu mudah untuk dicerna siswa sehingga sekolah terkesan lambat dalam melaksanakan program.

4. Struktur Birokrasi; meliputi sub fenomena pembentukan struktur organisasi, pembagian tugas dan koordinasi dari para pelaksana kebijakan. Belum adanya struktur organisasi, prosedur kerja, kewenangan dan penyebaran tanggung jawab yang jelas sehingga membuat implementasi pendidikan karakter menjadi kurang jelas. Respon dan tanggapan orang tua murid terhadap organisasi/ paguyuban kelas 
juga belum intens. Kordinasi dan pengawasan dari pemerintah, sekolah, walimurid dan pihak-pihak lain juga masih kurang. 